\title{
Gestational management of the patient with osteogenesis imperfecta: a case report
}

\author{
Gülşen Doğan Durdağ', Hakan Kalaycı', Seda Yüksel Şimşek', Songül Alemdaroğlu', \\ Gonca Çoban', Ferhat Şamlı \\ 'Gynecology and Obstetrics Clinic, Adana Application and Research Hospital, Faculty of Medicine, Başkent University, Adana, Turkey \\ ¿Department of Anesthesiology and Reanimation, Adana Application and Research Hospital, Faculty of Medicine, Başkent University, Adana, Turkey
}

\begin{abstract}
Objective: Osteogenesis imperfecta (OI) is a genetic disorder in which collagen synthesis is defective. It causes skeletal anomalies, and fragility in bones and tissues. In this case report, we aimed to present the gestational management of an OI patient and to discuss potential complications.

Case: Thirty-six-year-old patient diagnosed with Type I OI was followed up in our center due to her spontaneous pregnancy. A mutation was identified in COL1A1 gene of the patient. It was seen in her analysis by chorionic villus sampling that her fetal karyotype and COL1A1 gene were normal, and no pathology was found in the obstetric ultrasonography examinations. Fetal lung maturation of the patient, whose pain, respiratory distress and dyspeptic complaints increased as the week of gestation progressed, was evaluated by performing amniocentesis at 34 weeks of gestation, and a healthy baby was delivered by cesarean section at 35 weeks of gestation.

Conclusion: The concern of transferring genetic structure, difficulty of carrying pregnancy due to anatomic deformity and frequent gestational and labor complications are the major problems of OI patients. Genetic consultancy should be offered such patients and their followup procedures should be carried out by a multidisciplinary approach.
\end{abstract}

Keywords: Pregnancy, genetic consultancy, osteogenesis imperfecta, prenatal diagnosis.

\section{Introduction}

Osteogenesis imperfecta (OI), which is also known as glass bone disease, is a genetic disorder with different dominantly or autosomal recessively inherited subtypes. In Types I, II, III and IV patients, the synthesis
Özet: Osteogenezis imperfekta hastasının gebelik yönetimi: Olgu sunumu

Amaç: Osteogenezis imperfekta (OI), kollajen sentezinin hatalı olduğu bir genetik bozukluktur. İskelet anomalilerine, kemiklerde ve dokularda kırılganlığa sebep olmaktadır. Bu olgu sunumunda çerçevesinde, Oİ hastasının gebelik yönetimini sunmak ve karşılaşılabilecek komplikasyonları tartışmak istedik.

Olgu: Tip I Oİ tanılı 36 yaşındaki hasta, spontan gebeliği olması üzerine merkezimizde takibe alındı. Hastada COL1A1 geninde mutasyon tespit edildi. Koryon villus örneklemesinden yapilan analizde fetal karyotip ve COL1A1 geninin normal olduğu görüldü, obstetrik ultrasonografi incelemelerinde de patoloji izlenmedi. Gebelik haftası ilerledikçe ağrı, solunum sıkıntısı ve dispeptik şikayetleri artan hastaya 34 . haftada amniyosentez yapılarak fetal akciğer matürasyonu değerlendirildi. 35 . haftada sezaryen ile sağlıklı bir bebek doğurtuldu.

Sonuç: Genetik yapının aktarılma endişesi, anatomik deformite nedeniyle gebeliği taşımanın zorluğu, gebelik ve doğum komplikasyonlarının daha fazla görülebilmesi OI’lı hastalardaki temel problemlerdir. Bu hastalara genetik danışmanlık önerilmelidir ve takipleri multidisipliner yaklaşımla yapılmalıdır.

Anahtar sözcükler: Gebelik, genetik danışmanlık, osteogenezis imperfekta, prenatal tanı.

of type I collagen, which is an important structural protein for bones, tendons, ligaments and many connective tissues, is defective due to the mutations in COL1A1 and COL1A2 genes, and therefore fragility in bones, decreased bone density and skeletal anom-
Correspondence: Gülşen Doğan Durdağ, MD. Clinic of Obst. \& Gyn., Adana T\&R Hospital, Faculty of Medicine, Başkent University, Adana, Turkey. e-mail: gulsendogan@hotmail.com Received: October 9, 2018; Accepted: December 10, 2018

Please cite this article as: Doğan Durdağ G, Kalaycı H, Yüksel Şimşek S, Alemdaroğlu S, Çoban G, Şamlı F. Gestational management of the patient with osteogenesis imperfecta: a case report. Perinatal Journal 2018;26(3):162-166.

(C2018 Perinatal Medicine Foundation
Available online at: www.perinataljournal.com/20180263006 doi: $10.2399 /$ prn.18.0263006 QR (Quick Response) Code:

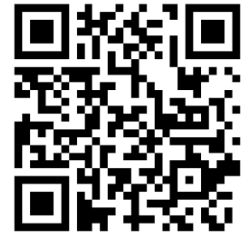


alies are seen in affected individuals. In addition, short height, scoliosis and spinal deformities, joint laxity, tendency to muscle and connective tissue injury, blue sclera, odontologic deformities, conductive hearing loss, hyperthermia, hyperhydrosis, platelet dysfunction, congenital cardiomyopathy, and fragility in other tissues such as joint, vessel and skin can be seen.

Today, it has been shown that about 20 different genes except COL1A1 and COL1A2 genes, which have a major role in the pathology, may cause OI. Although OI has 4 sub-groups classically, up to 15 different types have been reported according to clinical and radiological findings and underlying genetic reasons. ${ }^{[1]}$ Type $\mathrm{I}$ is the common one which has a better prognosis. ${ }^{[2]}$ Type II is the most slow-progressing form. Its usual prevalence is up to 6-7 in 100,000 and most of them are new mutations.

In our case report, we aimed to present the gestational follow-up and management of a patient with type I OI and to discuss potential complications.

\section{Case Report}

Thirty-six-year-old patient diagnosed with Type I OI admitted to our infertility center for preconceptional genetic diagnosis. The patient whose height was 148 $\mathrm{cm}$ and weight was $48 \mathrm{~kg}$ had the history of cholecystectomy and many surgeries for bone fracture; she had no known disease other than OI and migraine. In her family, only her brother had OI. It was planned to transfer healthy embryo by performing intracytoplasmic sperm injection and preimplantation genetic diagnosis (PGD) in order to eliminate the possibility of OI in her baby to be born. When planning the treatment process, the patient got pregnant spontaneously and the gestational follow-up was initiated for her. New generation full gene sequencing analysis was performed for the molecular genetic diagnosis; a mutation was identified in COL1A1 gene located on $17 \mathrm{q} 21.33$ chromosome region [p.R697 (c.2089C>T) (heterozygous)], but her COL1A2 gene located on $7 \mathrm{q} 21.3$ region was normal. Chorionic villus sampling was performed when she was at 12 weeks and 3 days of gestation according to her last menstrual period. Normal karyotype was seen in the karyotyping examination and sequencing analysis, and also it was found that COL1A1 gene was normal. No anomaly was observed in the detailed ultrasonographic examinations of the patient at 11-14 and 18-22 weeks of gestation. Oral glucose tolerance test was within normal range. The results of blood count, thyroid, liver and kidney function tests were normal. The patient was followed up for calcium, vitamin $\mathrm{D}$, phosphor, and ferritin. The patient was followed up under the control of physiotherapy and rehabilitation department and nutritionist, and her daily oral vitamin $\mathrm{D}$ intake was arranged as $2000 \mathrm{IU}$ and diet calcium as $1000 \mathrm{mg}$. Her weight was kept under control; the patient who was $48 \mathrm{~kg}$ before pregnancy was $54 \mathrm{~kg}$ during the delivery. Her blood pressure measurements were within normal ranges during all follow-ups. However, she had severe nausea and vomiting since the beginning of the pregnancy and she also had frequently repeating headache. As the week of gestation progressed, she frequently suffered stomachache and shortness of breath occasionally. Her complaint of being unable to eat due to gastric irritation, nausea and vomiting continued during the entire pregnancy period. The symptoms of the case were followed up until they regressed by routine follow-ups and sometimes several hospitalization after admitting to emergency service and also by intravenous hydration only under observation occasionally. By considering the possibility of preterm labor as the patient did not have any pain and had contractions in the tocography when she was at 27 weeks and 4 days of gestation, she was administered 2 doses of $12 \mathrm{mg}$ Betamethasone (Celestone Chronodose, $1 \mathrm{ml}$, Schering Plough Turkey, Istanbul) with 24-hour interval. The case did not have any cervical dilatation during the follow-up, her contractions regressed and the patient was discharged from the hospital and her gestational followup was continued. As her complaints increased as the week of gestation progressed, the patient underwent amniocentesis after 34 weeks of gestation was completed and her lecithin/sphingomyelin ratio was evaluated. This ratio was found 8 and her labor was planned considering that fetal lung maturation was completed. When she was at 35 weeks and days of gestation according to the last menstrual period, her labor was carried out by cesarean section under general anesthesia considering that the patient, whose contractions increased and had cervical effacement and $2 \mathrm{~cm}$ dilatation, would be less traumatized physically and psychologically compared to normal delivery. A singleton living female baby with a weight of $2330 \mathrm{~g}$ and height of $46 \mathrm{~cm}$ was born with 1-minute and 5-minute Apgar 
scores of 9 and 10, respectively. It was seen during the cesarean section that her skin, subcutaneous tissues, uterus muscle tissues and other connective tissues were very soft and fragile, so suturation was done carefully and gently. As the newborn was premature and had minimal respiratory distress, it was monitored in the intense care unit for 24 hours for observation purposes and then delivered to the mother. The patient had no hemorrhage during postoperative period, her hemoglobin values were stable, and she was administered Enoxaparin (Clexane 4000 anti-Xa IU, Sanofi Turkey, Istanbul) on the postoperative 1 st day to prevent thromboembolism risk. When the patient had subfebrile fever $\left(37.8^{\circ} \mathrm{C}\right)$ on the postoperative second day, her CRP value was checked and found high, and therefore broad-spectrum intravenous antibiotic treatment was initiated; her urine and blood culture tests were normal, and no infection focus was found. The patient whose CRP value regressed by the treatment was discharged from the hospital on the postoperative 4th day as her general condition was good and her vital signs were stable.

\section{Discussion}

The pregnancy of a patient with the diagnosis of osteogenesis imperfecta is a difficult process physically and psychologically. The concern of transferring defective genetic structure to the next generation, difficulty of carrying pregnancy due to anatomic deformity, frequent gestational complications such as antepartum bleeding, ablatio placentae, preterm labor and intrauterine growth retardation, frequent labor complications such as bleeding, uterine atony and stress fractures, thromboembolism and anesthesia risks are the problems that can be seen during the pregnancy of an OI patient. When offering genetic consultancy to such patients, the healthcare professionals should know the family history well, identify gene mutation and find out by appropriate methods if they are transferred to fetus or not. A healthy embryo can be transferred by PGD to a patient seen before the conception. However, more common method referred is to investigate current genetic mutation in mother's cells obtained by chorionic villus sampling or amniocentesis. Mutation is found in $70 \%$ of COL1A1 gene and in $30 \%$ of COL1A2 gene in OI cases associated with COL1A1-COL1A2. If no mutation is identified in
COL1A1 and COL1A2 genes, autosomal recessively inherited and OI-associated genes (CRTAP and LEPRE1) which are responsible for some of the cases are studied by also considering the family history.

OI diagnosis can also be established by USG examinations carried out during antenatal period. NT increase in early pregnancy, echogenicity decrease in long bones, bending and shortening of heights should bring OI to mind. The diagnosis of OI type I can be established by USG at the 17 weeks of gestation at the earliest; OI type II can be diagnosed at 13 weeks of gestation. $^{[3]}$ In types III and IV, there may be bending without any shortening in the bone length or decrease in its mineralization, and this may delay the diagnosis as it will be clear in the further weeks of gestation. When type III or IV OI is suspected, the results of repeating USG examinations should be compared. In order to confirm the diagnosis, fetal magnetic resonance imaging may also help in necessary cases. ${ }^{[3]}$

Due to the increase of body weight and change of the center of gravity during pregnancy, musculoskeletal system problems such as back pain, spinal deformities, scoliosis, and disk hernia increase. Bisphosphonates used routinely by this patient group is contraindicated for the pregnancy as they may cause fetal skeletal anomalies or congenital malformations, and many studies recommend discontinuing them after conception. ${ }^{[2,3]}$ However, these problems may be mitigated by calcium and vitamin D support and keeping weight gain under control. It has been shown that checking the values of calcium, phosphate, vitamin $\mathrm{D}$, parathyroid hormone, $\mathrm{LDH}$, CK, CRP, and kidney and liver function tests by a 3month laboratory analysis would help the management of treatment. ${ }^{[4]}$

The rates of gestational complications such as antepartum bleeding, ablatio placentae, preterm labor and intrauterine growth retardation are also higher in OI patients. It was shown in the previous years that the individuals with OI are more prone to bleeding and this may be associated with the platelet disorder. ${ }^{[5]}$

Ruiter-Ligeti et al. reported that antepartum bleeding or ablatio placentae risk may be associated with collagen defect or coagulation defect, but they did not find any increase in the risk of postpartum bleeding. ${ }^{[1]}$ In the same study, the authors found the risk of venous thromboembolism higher in women with OI and they associated it with the high rates of cesarean section and 
prolonged immobilization related with postnatal skeletal problems. ${ }^{[1]}$

Also, the studies showing that calcium metabolism has a role in the pathogenesis of preeclampsia indicate that the risks for preeclampsia and intrauterine growth retardation are increased in these patients. ${ }^{[2]}$

The increase in preterm labor risk may be associated with antenatal bleeding, ablatio placentae, premature rupture of membrane or intrauterine growth retardation as well as maternal complications. ${ }^{[1,6]}$ In our case, tightness and abdominal pain felt by the mother as the uterine got bigger, back and lumbar pain, shortness of breath and gastric irritation findings such as severe nausea and reflux made maintaining the pregnancy difficult; therefore, after we confirmed the fetal pulmonary maturation, we informed the family that newborn might need intense care support as it was a premature baby, and we planned the labor by obtaining the approval of the family.

Although there is no certain suggestion for the delivery type for patients with OI, cesarean section is usually preferred for the delivery as an effort to decrease labor trauma. Maternal fracture incidence does not increase during pregnancy; however, small traumas due to obstetric manipulations may increase the fracture risk. Stress fractures related with bone demineralization can be seen both in vaginal labors and cesarean section labors. It has been reported that such fractures can be minimized by careful positioning during delivery or surgery and performing preconceptional bisphosphonate treatment. ${ }^{[1,3,6,7]}$ In addition, spontaneous uterine rupture was also reported during labor. ${ }^{[8]}$ Labor induction is not recommended since it is not possible to predict how uterine contractions will develop in the presence of defective collagen. ${ }^{[2]}$ Feng et al. reported that a patient with OI who prefers vaginal labor should be managed as if she is a patient with scarred uterus, and they highlighted that postpartum bleeding risk is high depending on the uterine atony, laceration or thrombocyte disorder. ${ }^{[3]}$ Presentation anomalies and cephalopelvic disproportion associated with maternal skeletal anomaly can be cesarean section indications. Labor by cesarean section can also be considered for a fetus established with OI diagnosis in order to minimize the labor trauma. However, the studies show that cesarean section do not decrease the rates of newborn fractures during labor. ${ }^{[1,3,9]}$
In addition, labor by cesarean section should not be considered as free of risk, and it should be remembered that it may increase the risks such as thrombosis, uterine atony, and postpartum bleeding. ${ }^{[2]} \mathrm{We}$ decided that labor by cesarean section would be more appropriate for our case considering pelvic or vertebral fracture or uterine rupture risks.

For anesthesia, all general, epidural and spinal anesthesia methods can be used; however, both general and regional methods may have risks. Cardiopulmonary condition of the patient should be evaluated well. In the general anesthesia, difficult intubation due to skeletal deformities, mandibular or dental fractures may occur; malign hyperthermia risk should also be considered. In regional anesthesia, the procedure related with spinal deformities is technically difficult, and it may also get hard to adjust block level. ${ }^{[2,3]}$

Breastfeeding of the patients with OI may also be considered contraindication relatively. Although there is no full consensus, it is recommended to avoid log-term breastfeeding periods particularly in patients who have vertebral fracture in order to shorten this process which may cause a certain decrease in the bone density. ${ }^{[10]}$

\section{Conclusion}

Osteogenesis imperfecta is a condition with high maternal morbidity risk during pregnancy. Preconceptional consultancy and medical and genetic evaluation should be offered to all women with OI.

The type and severity of the disease and general clinic condition of patient should be considered in order to minimize the complications, and these patients should be followed up at fully equipped tertiary hospitals through a multidisciplinary approach.

Conflicts of Interest: No conflicts declared.

\section{References}

1. Ruiter-Ligeti J, Czuzoj-Shulman N, Spence AR, Tulandi T, Abenhaim HA. Pregnancy outcomes in women with osteogenesis imperfecta: a retrospective cohort study. J Perinatol 2016; 36:828-31.

2. Cozzolino M, Perelli F, Maggio L, Coccia MA, Quaranta M, Gizzo S, et al. Management of osteogenesis imperfecta type I in pregnancy; a review of literature applied to clinical practice. Arch Gynecol Obstet 2016;293:1153-9.

3. Feng Z, Chen Q, Shi C, Wen H, Ma K, Yang HX. A type IV osteogenesis imperfecta family and pregnancy: a case report 
and literature review. Chin Med J (Engl) 2012;125:135860.

4. Pabinger C, Heu C, Frohner A, Dimai HP. Pregnancy- and lactation-associated transient osteoporosis of both hips in a 32 year old patient with osteogenesis imperfecta. Bone 2012;51: $142-4$.

5. Hathaway WE, Solomons CC, Ott JE. Platelet function and pyrophosphates in osteogenesis imperfecta. Blood 1972;39: 500-9.

6. Yimgang DP, Shapiro JR. Pregnancy outcomes in women with osteogenesis imperfecta. J Matern Fetal Neonatal Med 2016; 29:2358-62.

7. Chen CP, Lin SP, Su YN, Huang JP, Chern SR, Su JW, et al. Uncomplicated vaginal delivery in two consecutive pregnancies carried to term in a woman with osteogenesis imperfecta type I and bisphosphonate treatment before conception. Taiwan J Obstet Gynecol 2012;51:305-7.

8. Krishnamoorthy U, Vausse S, Donnai P. Management of pregnancy complicated by maternal osteogenesis imperfecta. Report of a case with uterine rupture. J Obstet Gynaecol 2002; 22:316.

9. Bellur S, Jain M, Cuthbertson D, Krakow D, Shapiro JR, Steiner RD, et al.; Members of the BBD Consortium, Nagamani SC. Cesarean delivery is not associated with decreased at-birth fracture rates in osteogenesis imperfecta. Genet Med 2016;18:570-6.

10. Mcallion SJ, Paterson R. Musculo-skeletal problems associated with pregnancy in women with osteogenesis imperfecta. J Obstet Gynaecol 2002;22:169-72. 